University of Wollongong

Research Online

Faculty of Business - Papers (Archive)

Faculty of Business and Law

$1-1-2015$

Utilising a change management perspective to examine the implementation of corporate rebranding in a non-profit SME

Paul A. Chad

University of Wollongong, pchad@uow.edu.au

Follow this and additional works at: https://ro.uow.edu.au/buspapers

Part of the Business Commons

Research Online is the open access institutional repository for the University of Wollongong. For further information contact the UOW Library: research-pubs@uow.edu.au 


\title{
Utilising a change management perspective to examine the implementation of corporate rebranding in a non-profit SME
}

\author{
Abstract \\ The purpose of this article is to use a change management perspective to investigate how a non-profit \\ SME conducted corporate rebranding and determine in this important new context the usefulness of the \\ principles of corporate rebranding developed by Merrilees and Miller primarily in relation to large for-profit \\ organisations. Research is based upon case study of an Australian non-profit SME health insurance \\ organisation that recently conducted corporate rebranding. Via a change management perspective \\ incorporating a discourse transformation framework, semi-structured in-depth interviews with managers \\ and employees examined the rebranding process and explored manager and employee experiences of the \\ journey. The rebranding was successful. Crucial was thorough situation analysis, well-developed \\ implementation plan, and early buy-in from employees subsequently involved throughout the \\ implementation process. Although evidence of all principles of corporate rebranding was detected within \\ the actual rebranding process utilised, various refinements to the principles are recommended. These \\ refined principles can guide practitioners in future corporate rebranding exercises. The research \\ contributes by successfully introducing a change management perspective utilising a discourse \\ transformation framework into examination of corporate rebranding. The research also extends the \\ principles of corporate rebranding to a new context and importantly provides suggested refinements to \\ the principles.
}

\section{Keywords}

implementation, corporate, rebranding, non, profit, change, management, sme, perspective, utilising, examine

\section{Disciplines}

Business

\section{Publication Details}

Chad, P. (2015). Utilising a change management perspective to examine the implementation of corporate rebranding in a non-profit SME. Journal of Brand Management, 22 (7), 569-587. 
Title:

Utilising a Change Management Perspective to Examine the Implementation of Corporate Rebranding in a Non-profit SME

$\underline{\text { Short running title: }}$

Implementing corporate rebranding in Non-profit SMEs

Author Name:

Dr Paul Chad

Biography:

Dr Paul Chad is a Lecturer in Marketing at the University of Wollongong in Australia. His research interests include corporate rebranding, market orientation, marketing strategy, the nonprofit sector and qualitative research techniques.

\section{Contact details:}

Email:pchad@uow.edu.au

Postal address:

School of Management, Operations \& Marketing

University of Wollongong

Wollongong 2522

Australia

Fax: +61 242215154

Telephone: +61 242214413 


\title{
Utilising a Change Management Perspective to Examine the
}

\section{Implementation of Corporate Rebranding in a Non-profit SME}

\begin{abstract}
The purpose of this paper is to use a change management perspective to investigate how a nonprofit SME conducted corporate rebranding and determine in this important new context the usefulness of the principles of corporate rebranding developed by Merrilees and Miller (2008) primarily in relation to large for-profit organisations. Research is based upon case study of an Australian non-profit SME health insurance organisation that recently conducted corporate rebranding. Via a change management perspective incorporating a discourse transformation framework, semi-structured in-depth interviews with managers and employees examined the rebranding process and explored manager and employee experiences of the journey. The rebranding was successful. Crucial was thorough situation analysis, well-developed implementation plan, and early buy-in from employees subsequently involved throughout the implementation process. Whilst evidence of all principles of corporate rebranding was detected within the actual rebranding process utilised, various refinements to the principles are recommended. These refined principles can guide practitioners in future corporate rebranding exercises. The research contributes by successfully introducing a change management perspective utilising a discourse transformation framework into examination of corporate rebranding. The research also extends the principles of corporate rebranding (Merrilees and Miller, 2008) to a new context and importantly provides suggested refinements to the principles.
\end{abstract}

Key words - corporate rebranding, change management, non-profit, SME, case study, branding. 


\section{Introduction}

Organisations operate in an ever-changing environment and must adapt to survive (Lee, 2013). It is probable corporate rebranding will be required during the life of an organisation. However, corporate rebranding exercises are risky and often require large investments (Gotsi and Andriopoulos, 2007) with no guarantee of success (Amujo and Otubanjo, 2012). If a corporate rebranding activity is unsuccessful, corporate brand equity established over a number of years may be diminished (Stuart and Muzellec, 2004).

Whilst corporate branding is well-researched (e.g. Balmer and Gray, 2003; de Chernatony and Dall’Olmo Riley, 1998; Hatch and Schultz, 2003), corporate rebranding is under-researched (Miller and Merrilees, 2013) and “embryonic” (Juntunen, 2014, p. 114). Problematically, the majority of existing corporate rebranding research concentrates only on 'why' rebranding occurs, not upon 'how' it can be conducted successfully in practice (Plewa et al., 2011). Specifically in relation to 'how' corporate rebranding can potentially be implemented successfully in practice, Merrilees and Miller (2008, p. 537) proposed six “principles of corporate rebranding”. A limitation however is these principles were developed based primarily upon examination of various large, for-profit organisations. To date, the principles have been assessed in a limited range of organisational settings. Miller and Merrilees (2011, p. 317) suggest “[o]ther studies are desirable, to reinforce this framework, modify it or replace it with a superior conceptualisation”. Specifically in relation to non-profit organisations (NPOs) and small-to-medium sized enterprises (SMEs), it is currently not known 'how' non-profit SMEs can conduct corporate 
rebranding, nor indeed if the Merrilees and Miller (2008) 'principles of corporate rebranding' developed based upon examination of large for-profit organisations may be of any use in guiding managers within the non-profit SME context. The current research aims to address these gaps.

Given the important role that NPOs play within society and the economy (Salamon and Sokolowski, 2006), coupled with the distinct differences in organisational dynamics between forprofit and non-profit organisations, the non-profit sector represents a worthwhile arena in which to examine corporate rebranding. Likewise, given the role SMEs play within the economy, typically accounting for $60-70 \%$ of jobs (OECD, 2015), and the different dynamics between large and smaller organisations, SMEs represent a fruitful area in which to examine corporate rebranding.

A limitation of existing corporate rebranding research is concentration upon managerial views, more so than employee views (Lee, 2013). This is surprising given the crucial role employees play in delivering the brand to the market place.

Therefore, the purpose of this paper is to make advances in the corporate rebranding research field by incorporating an employee focus into determining 'how' corporate rebranding was implemented in relation to a non-profit SME setting and test the six principles of corporate rebranding (Merriless and Miller, 2008) within this setting. The objectives of the study were-

- To find out how non-profit SMEs attempt to implement corporate rebranding.

- Given the differing dynamics between for-profit and non-profit organisations, and between large and smaller organisations - find out if the principles of corporate rebranding proposed by Merrilees and Miller (2008) based upon examination of large organisations are in evidence within non-profit SMEs.

- To pioneer a change management perspective utilising a discourse transformation framework to highlight employee views. 
This study contributes to the corporate rebranding literature in some meaningful ways: (i) it fills a key gap and addresses the call from Brexendorf et al. (2012, p. 256) for branding research covering “neglected” and “emerging or evolving” areas of branding; (ii) it fills a gap by extending examination of the principles of corporate rebranding (Merrilees and Miller, 2008) into a new context; (iii) the findings suggest refinement to the principles of corporate rebranding developed by Merrilees and Miller (2008); (iv) this is the first known research to utilise a change management lens (using a discourse transformation framework) to examine the corporate rebranding process, the benefit of which was evaluation of employees who are crucial in delivery of successful rebranding; (v) the findings provide guidance for non-profit SME managers regarding how to conduct a corporate rebranding; and (vi) the research is based upon real-life activity, hence addressing calls from Tadajewski and Hewer (2011, p. 451) for improved “understanding how practitioners engage in marketing activities”.

The paper is structured as follows. First, a theoretical background provides an overview of corporate rebranding, describes the change management perspective, details the Miller and Merrilees (2008) principles of corporate rebranding, then highlights the unique characteristics of non-profit versus for-profit organisations as well as the differences between SMEs and large organisations, which could potentially have an impact upon implementation of corporate rebranding. Second, details of the research approach are provided. Third, the findings of the research are presented. Fourth, discussion of the theoretical and managerial contributions is provided, as well as limitations of the current research with recommendations for future research. 


\section{Theoretical background}

\section{Corporate branding}

“A corporate brand is the visual, verbal and behavioural expression of an organisation's unique business model” (Knox and Bickerton, 2003, p. 1013) and connotes certain information, emotions, personality and levels of quality and performance to target audiences (Balmer and Gray, 2003). Hence, it is a "profile builder" amongst key stakeholders including customers, employees and investors (Balmer et al., 2006, p. 137). The most visible aspects of a corporate brand are an organisation's name, tagline and logo design (Hankinson et al., 2007). Given corporate branding targets multiple stakeholders (both internal and external), management must appreciate and respond to the attitudes of a diverse audience (de Chernatony, 1999).

\section{Corporate rebranding - reasons to rebrand}

Corporate brands should be revitalized regularly to stay relevant (Merrilees, 2005), with corporate rebranding being an opportunity to signal a new strategic focus to stakeholders (Lambkin and Muzellec, 2008). Reasons for corporate rebranding include organisational mergers/de-mergers, managerial change with subsequent new organisational directions, marketplace shifts, response to competitive activity, updating of corporate image and change (expansion or contraction) in range of operations (Baker and Balmer, 1997; Muzellec et al., 2003). When considering a corporate rebrand, management must determine in what way, and to what extent the brand should be changed (Merrilees and Miller, 2008). Crucially however, prior to finalising any rebranding decision, a cost/benefit analysis should be conducted as rebranding costs are usually very high (Stuart and Muzellec, 2004). 


\section{Components of rebranding}

Corporate rebranding addresses one to four components - name, logo, tagline and positioning (Stuart and Muzellec, 2004). Change of organisational name is commonly used to indicate a transition in organisational identity (Melewar and Karaosmanoglu, 2006), however, a name change is a big step and must be carefully considered. Logo re-design can be made quickly, but takes time to implement as all collateral containing the old logo needs to be replaced. Taglines are relatively quick to change, but crucial in reflecting the desired organisational image to stakeholders. Associated with name, logo and tagline changes, corporate rebranding can also involve re-positioning which aims to assign new meaning to the corporate brand and communicate new benefits to stakeholders (Stern, 2006).

\section{Employee involvement - crucial to success}

Branding is "an exercise in management of meaning” and not only informs external stakeholders about organizational values but "also potentially instructs and directs" internal stakeholders (Kärreman and Rylander, 2008, p. 103). Corporate brand personality reflects "values, words and actions of employees, individually and collectively” (Keller and Richey, 2006, p. 75). When employees share the brand values, they are more likely to deliver and communicate the brand promise (Baumgarth, 2010; Hatch and Schultz, 2003; Lee, 2013). Ideally, employees should live the brand (Gotsi and Wilson, 2001) in their daily behaviour and actions (de Chernatony and Segal-Horn, 2001). Stuart (2012) suggests the level to which employees will live a new brand following rebranding is related to the extent and manner to which employees identify with the rebrand, as well as the specific nature of the rebranding activity and internal communication. 
Corporate rebranding - a change management perspective

Corporate rebranding can be regarded as a change management activity (Gotsi and Andriopoulos, 2007), with organisational change defined as "new ways of organizing and working" (Andriopoulos and Dawson, 2009, p. 14). Thus, during corporate rebranding, management need to move employees from an existing, to a new mindset/culture matching new corporate brand values (Gotsi et al., 2008). However, brand meaning is constructed and contested in interactions between stakeholders (including employees and management) (Motion et al., 2003) "whose expectations and interpretations may differ” (Lee, 2013, p. 1127). During a rebranding, employees' identity can be challenged, therefore introducing change should be an adaptive process providing time for employees to learn new ways of thinking, doing (Mintzberg, 1994), and understanding or knowing the world differently (Motion and Leitch, 1996). When considering change, management should be aware of potential internal resistance from employees and subsequently design and implement a "well-structured change management program to gain buy-in” (Merrilees and Miller, 2008, p. 538) otherwise divisions can prevent brand revitalisation (Gyrd-Jones et al., 2013). To assist buy-in, it is helpful to ensure a connection between the old brand and the new, so stakeholders (both internal and external) are not alienated (Gotsi and Andriopoulos, 2007). Linked to this, key stakeholders should be involved in the rebranding process from start to finish (Lee, 2013), to increase probability of successful corporate rebranding (Balmer, 2001).

Significantly, despite employees being crucial to brand delivery, existing research regarding implementation of corporate rebranding lacks examination from an employee perspective (Melewar et al., 2012; Lee 2013), a key issue this current research seeks to address. 


\section{Principles of corporate rebranding}

In terms of 'how' corporate rebranding can be conducted, Merrilees and Miller (2008, p. 539) identified four specific case studies that "make major contributions to understanding corporate rebranding”. These being: Mazda - South Africa (Ewing et al., 1995), LEGO group (Schultz and Hatch, 2003), Eircell/Vodafone - Ireland (Daly and Moloney, 2004) and Canadian Tire (Merrilees, 2005). Three themes were identified by Merrilees and Miller (2008) from these studies. First, a requirement for brand re-vision based upon understanding of consumers to meet their existing and expected future needs. Second, use of internal marketing to ensure employee commitment. Third, use of advertising and other marketing mix elements during implementation of corporate rebranding. These three themes were expanded by Merrilees and Miller (2008) into six principles of corporate rebranding -

- The first theme (brand re-vision) contained three principles. Principle 1 involves satisfying the core ideology of the corporate brand and also progressing the brand to remain relevant to contemporary conditions. Principle 2 requires retention of some brand concepts to build a bridge from the existing to revised corporate brand. Principle 3 requires meeting the needs of both the existing and new market segments.

- The second theme contains Principle 4 that suggests organisations with high levels of brand orientation delivered via communication, training and internal marketing are likely to have effective corporate rebranding.

- The third theme contains Principles 5 \& 6. Principle 5 emphasises high levels of integration and coordination of all aspects of the marketing mix. Principle 6 stresses use of promotion to inform all stakeholders of the revised brand. These six principles were subsequently supported by examination of corporate rebranding at Acton Leather Company, a Canadian for-profit organisation (Merrilees \& Miller, 2008). 
Since the development of these six principles of corporate rebranding (based primarily upon examination of large, for-profit organisations), limited research has been conducted to assess the utility of these principles in additional settings. Miller and Merrilees (2011) evaluated reported findings from a number of previously published rebranding papers and identified evidence of some of the principles but also found no evidence of other principles. This research could be considered limited and problematic as it simply looked for evidence of the principles in pre-existing published research, the majority of which was published to report a range of aspects of rebranding, not the specific implementation process. It is therefore unclear whether the lack of evidence of the principles was due to data existing, but simply not being reported in the studies examined, or whether specific principles of corporate rebranding were indeed non-existent. More recently, Calderwood and Freathy (2014) examined rebranding of a UK co-operative (for-profit) organisation and identified evidence of Merrilees and Miller's (2008) six principles of corporate rebranding. Similarly, Brophy (2014, p. 100) examined the name change of an Irish insurance company following takeover by a US organisation and concluded "all principles were adhered to". This limited amount of literature examining the principles of corporate rebranding developed by Merrilees and Miller (2008) is problematic and provides opportunity for further investigation, which this current research provides.

\section{Corporate rebranding of non-profit organisations}

Whilst the marketing discipline was developed in the for-profit arena, it is generally accepted that marketing (including activities such as corporate branding/rebranding) is also relevant for NPOs. However, NPOs "possess certain characteristics" making them different to for-profit organisations (Khan and Ede, 2009, p. 337). Key differences and characteristics of NPOs can include - use of volunteers, extent of for-profit competition, sources/level of access and use of 
funds (Andreasen and Kotler, 2008). Crucially, NPOs have a different emphasis compared to forprofit organisations, operating solely for the clients, whereas for-profit organisations ultimately report to stock-owners wanting capital stock growth and/or regular stock dividends.

Thus, given the differences between for-profit and non-profit organisations, theory developed in the for-profit sector may not necessarily be directly transferable to the non-profit sector, and may, or may not, require specific modification for the non-profit sector. Hence, at present, it is unknown whether the principles of corporate rebranding developed by Merrilees and Miller (2008) in relation to for-profit organisations are directly transferable, or need modification for NPOs. This current research addresses this gap.

In regards to branding research within NPOs, "published material ... is scarce” (Khan and Ede, 2009, p. 336). Specifically in relation to rebranding, the first known examination of rebranding using the principles of rebranding (Merrilees and Miller, 2008) in a non-profit context was conducted by Miller and Merrilees (2013) who acted as 'consultants' using action research to introduce a rebranding into a small disability services organisation reliant upon volunteers and sourcing funds from government tenders and donations. The principles of corporate rebranding (Merrilees and Miller, 2008) were used to guide the rebranding. When referring to the term 'nonprofit', care needs to be taken as the sector covers a wide range of sub-sectors. For example charities, member-based organisations and political parties. The Miller and Merrilees (2013) examination was limited to a specific sub-sector of the non-profit sector. Miller and Merrilees (2013, p. 178) concluded that further studies "in other types" of non-profit organisations should be conducted.

Funding is generally tight within NPOs, and employees often baulk at expenditure on 'marketing' activities that employees often see as unnecessary, with the funds perceived as better 
spent directly on clients. It is therefore postulated that employees in NPOs may question the benefit of conducting a corporate rebranding and subsequently resist. This suggests a smooth corporate rebranding within NPOs could be problematic, particularly in regards to Principle 4 (delivery of high levels of brand orientation) in the Merrilees and Miller (2008) principles of corporate rebranding. Examination of this key issue provides further justification for the current research.

\section{Corporate rebranding of SMEs}

Marketing is relevant for all organisations irrespective of size (Gilmore et al., 2001). However, there are differences between large organisations and SMEs that can potentially affect the manner in which SMEs conduct marketing activities (including corporate rebranding). The inherent characteristics of the SME owner/manager and stage of development of the organisation can influence marketing activities. Issues for SMEs include limited resources (finance, time, expertise) as well as impact (low market share) in the marketplace (Carson, 1990). Within SMEs, organisational values are influenced by owner/manager values, and often based upon the small structure and relative informality of most SMEs. Values evident in SMEs more so than larger organisations include "team-playing, commitment, open communications, creativity and honesty, flexibility, motivation and innovative thinking” (Centeno et al., 2013, p. 455).

Thus, inherent aspects of SMEs may influence the manner in which marketing activities including brand management are conducted. In regards to branding within SMEs, Wong and Merrilees (2005, p. 156) were unable to “discern one research study dedicated to SME branding”, and more recently Centeno et al. (2013, p. 747) considered “[r]elatively few studies focus specifically on SME brand research”. Indeed, rebranding appears to have been basically ignored. 
It is postulated that the typically limited resources (both financial and internal staff) characteristic of SMEs could make rebranding problematic. Management may struggle to accept spending money on the various costs associated with corporate rebranding, including employing a rebranding consultant (due to no internal expertise), plus the time required for employer communication/training and generation of new marketing collateral. This particularly has potential impact upon Principle 4 (brand orientation) and Principle 6 (promotion to inform stakeholders of the brand revision) of the Merrilees and Miller (2008) principles of corporate rebranding. However, indeed conversely, it is also postulated that the small size of SMEs could make communication and gaining employee buy-in (Principle 4) easier than within a large organisation, upon the proviso that appropriate expertise and funds are allocated. Examination of these issues provides further justification for the current research.

\section{Research approach}

Given the aim of the research was to examine 'how' corporate rebranding occurs within an organisation, case study was selected as an appropriate research approach as case studies are the preferred strategy when 'how' questions are posed and when there is a focus on a real-life context (Singh, 2014). Additionally, case studies provide holistic, in-depth investigation of complexity and context (Eisenhardt 1989, Muzellec and Lambkin, 2007), appropriate to address the aims of this research. Case studies are "the hallmark research approach for corporate rebranding studies" (Miller and Merrilees, 2013, p. 174). The current research involved thematic analysis of data derived from a single case study. Relative to multiple case studies, a single case enables greater immersion into the organisation, providing more in-depth information for the same amount of 
resources utilised (Gyrd-Jones et al., 2013). Also, the benefit of a single case is that it can be utilised as a way to modify existing generalisations (Stake, 1995).

The research was guided by the "rigorous research design" for case studies developed by Johnston et al. (1999, see pp. 205-210). The specific case organisation was selected as it was known to have experienced an attempt to introduce corporate rebranding in recent years. The time lag (approximately 18 months) between rebranding and subsequent study provided time for the organisation to embed change, determine results, and for management and employees to reflect upon and crystallise their thoughts regarding their experiences of the rebranding journey. The author of this paper was not involved in the rebranding activity.

\section{The case organisation}

Peoplecare is a non-profit SME competing within the Australian health insurance industry against predominantly for-profit organisations, including large multi-national organisations such as Bupa. Formed in 1953 to provide health insurance for employees within the Australian steel industry, Peoplecare broadened its base in 2006 to offer health insurance products to the entire community. The evolution of Peoplecare resulted in management wanting to re-position for the future by revising its corporate brand to appeal to not only existing customers, but increase awareness within the broader community, particularly the younger-age segment who Peoplecare identified as the prime target growth segment. As noted by Merrilees and Miller (2008, p. 541), growing a "brand might require tapping into additional target markets with different needs from the original brand customer base”. This is indeed true within Peoplecare, who regarded the younger-age segment as their new target growth segment.

Peoplecare currently provides 30,000 policies covering 80,000 people as well as 170,000 international students studying within Australia. To guide the rebrand, Peoplecare commissioned 
a branding consultancy. The evolutionary rebranding commenced in 2010 and involved maintaining the same name, but changing logo, tagline, re-positioning with a focus upon a younger demographic, and highlighting a 'personal is best' point of differentiation. Maintaining the same name was considered by the organisation to be appropriate as it directly identified what the organisation provided - 'people' with 'care'.

\section{Data collection process}

Corporate rebranding can be regarded as a change management activity (Gotsi and Andriopoulos, 2007). The current research utilises a change management perspective to assess how corporate rebranding was conducted within Peoplecare, the resultant change, and subsequently aims to identify any evidence of the Merrilees and Miller (2008) principles of corporate rebranding. To examine the change process, a discourse transformation framework was utilised based upon Foucault’s (1991, pp. 56-57) criteria for “detecting changes which affect discursive formations” namely, "displacement of boundaries", "the new position and role” of employees, the "new mode of functioning of language" and the "circulation" of the new discourse. This framework has previously been utilised successfully to examine organisational change relating to various marketing activities in a range of organisations (Author's own). The benefit of examining change via this discourse transformation framework is that it concentrates on detection and identification of what changes have occurred, how they occurred, and the reaction/effect upon employees within the organisation. Employees are the very people required to live and deliver the brand within the rebranded organisation, and have often been over-looked in previous corporate branding research (Melewar et al. 2012, Lee, 2013).

A case study protocol was developed as a "major tactic in increasing the reliability" (Yin, 1994, p. 63). Semi-structured, in-depth, face-to-face individual interviews utilising open-ended 
questions were conducted with a range of participants (both management and employees) from all organisational levels and all functional departments, as well as with the consultants to assist with data triangulation. Purposeful sampling enabled selection of "respondents to access the best quality data about a given subject” (Khan and Ede, 2009, pp. 341-342). Sampling stopped upon saturation, providing "sufficient data for those arguments to be well grounded" (Wood and Kroger 2000, p.81).

Interview protocol questions were based upon Foucault's (1991, pp. 56-57) criteria for “detecting changes which affect discursive formations”. Following participants' consent, interviews were digitally recorded. A single researcher conducted all interviews to ensure consistency and minimise bias (Lincoln and Guba, 1985). Interview recordings were transcribed and checked by the researcher for accuracy, then provided to participants for final checking.

\section{Data analysis}

Manual thematic analysis of interview transcripts and other available evidence was conducted utilising guidelines recommended by Creswell (2003, pp. 191-195) and Patton (2002, pp. 465468). Interview transcripts were supplemented by additional data sources including organisational documents, press releases, internet sites, newsletters, annual reports and researcher observation of organisational activities.

To assist research validity, the eight strategies suggested by Creswell (2013, pp. 250-253) were utilised. Hence, to assist triangulation, a range of data sources was utilised. Memberchecking involved provision of interview transcripts to participants to verify accuracy. Rich, thick description was utilised during writing up of results, with appropriate participant quotations, to provide a shared experience to readers. Prolonged time was spent in the field, peer debriefing 
provided an independent perspective of the developing research results, and two independent external auditors examined the research.

Comments from interview participants are indicated in italics in the following sections.

\section{Findings}

Corporate rebranding is a form of change, and change requires a catalyst. Leadership is a major issue in rebranding (Miller et al., 2014). Peoplecare possessed a pro-active Chief Executive Officer (CEO) who saw the need to change, and with approval from the Board of Directors initiated corporate rebranding. Pro-activeness enabled planned change at an appropriate time in the evolution of the organisation, before issues necessitating the rebranding became problematic. The dominant influence of this CEO is a typical characteristic of SMEs. The rebranding process requires a thorough and considered approach to ensure success. Rebranding exercises are costly both in terms of monetary outlay and employee time resources. Some organisations aim to minimise costs by utilising consultants as little as possible, and doing as much of the rebranding work in-house as possible. This can be fraught with danger as the relatively infrequent activity of rebranding typically means organisations typically don’t possess in-house expertise appropriately knowledgeable in rebranding. Recognising this, Peoplecare employed an external brand consultancy that worked closely with the CEO and General Manager of Marketing. 
Theme 1 - Brand Re-visioning - Principles 1-3.

Principle 1 - Satisfy core ideology of corporate brand, yet progress the brand to remain relevant to contemporary conditions.

Peoplecare had operated as a relatively formal, conservative health insurer. As indicated by the General Manager of Marketing - 'We had a nice brand ... but it was pretty conservative and the same as other companies ... we also found we weren't attracting a fair share of younger people'. The rebranding change involved continued emphasis of the personal nature of Peoplecare's service delivery, plus, as indicated by the CEO - 'backed up by a strong visual presence both in strength of colour as well as style, a tone of voice [that was] a bit out there ... a bit more chatty, conversational, less structured, less corporate ... a space that no other health insurer occupied'. The result was a 'fresh and cheeky' rebrand involving new logo, tone of voice, colours and tagline - 'love people', aimed at a younger demographic without alienating existing older members. Examples of Peoplecare's before and after logos and colours are indicated in Exhibit 1. Brands utilising symbols as logos are more effective than logos purely consisting of brand names (Park et al., 2013). The Peoplecare logo seemingly combines the best of both worlds by possessing both a symbol and name.

INSERT EXHIBIT 1 HERE 
The new discourse involved a major shift in language - a new 'tone of voice' both internally and externally. As indicated by a manager - 'much less formal ... the way we communicate with our staff and our members, it's very chatty, very vibrant, very high energy. It's warm, the language we use is completely different across the board'. Similarly, a frontline employee commented - 'we changed all our communications, to get rid of all that jargon and technical stuff'. Both verbal and written communication changed - 'documents were reworded to our new kind of speak'. This required rewording of numerous templates 'back to layman's terms' with 'the actual tone changed to make it a bit more casual and as easy as possible to understand'. Relevant employees were trained in the new 'tone of voice' - 'it was a significant change and this took some time for staff to become proficient at the new way of writing'. Thus, Principle 1 was supported as Peoplecare maintained their core ideology of personal service, but also progressed the brand to remain relevant to contemporary conditions.

Principle 2 - Retain at least some brand concepts to build a bridge from existing to revised corporate brand.

Based upon the initial origins and heritage of the organisation, Peoplecare pride themselves on the personal approach. Peoplecare ensured maintenance of this personal service focus. This acted as a bridge to assist buy-in from existing members who knew the non-profit heritage of the organisation, as well as gain buy-in from existing employees as they were used to the mode of operation. Indeed, it has been expanded and emphasised via inclusion of the 'love people' tagline. Thus, Principle 2 is supported. 
Principle 3 - Meet needs of new market segments whilst also supporting existing brand segments.

Peoplecare targeted a new market - the younger demographic. Existing member needs were supported via maintaining all existing products and services. The needs of the new market segment that are technology savvy were met by introducing new communication processes based around electronic options. These included online claims processing, online newsletter delivery and online do-it-yourself health assessments. Principle 3 was therefore supported.

Theme 2 - Attaining Internal Support / Stakeholder 'buy-in' - Principle 4.

Principle 4 - High level of brand orientation via communication, training and internal marketing.

Led by the consultant, extensive research and activity (one year) was conducted prior to the rebranding launch. Stakeholder involvement was a key aspect for the consultant. The research conducted by the consultant involved all stakeholders, including employees. As indicated by a middle manager - 'the branding has been a big change, but the organisation has taken the employee on the journey'. From the outset, senior management recognised the need to involve employees. As noted by the General Manager of Marketing, the first step was to gain employee buy-in - 'explaining what the current situation is, explaining what the change is going to be, what the impact is going to be, what we need to do and where we want to end up ... it's about communicating, consulting the staff'. Involvement of the employees at all stages of rebranding occurred and smoothed the way to gaining employee buy-in, resulting in a successful rebrand because, as indicated by a middle manager, employees 'had a say and contributed to the brand ... the look and feel which gives them the sense of ownership ... and the fact too that they're the face of the organisation, our marketing materials and brochures [feature] them and their families, so 
that builds that camaraderie and spirit'. As summed up by a frontline service provider - 'we've been allowed to be on that journey'. The rebrand involved new modes of service delivery, so training was a key element to ensure success, with a senior manager stating - 'we make sure everybody's properly trained before the changes take place'.

Within Peoplecare, the switch from a conservative style of operation to a bright, bubbly, relaxed and highly personal organisation resulted in a new way of operating for employees. Whilst the rebranding resulted in change for employees, most employees embraced the more casual approach, impacting positively on employee behaviour, with a middle manager commenting - 'it's a more fun type of look and feel, you tend to be a little bit more relaxed ... this [has] livened things up and made it a bit more fun'. A service provider stated - 'it takes away the ego of the organisation. It makes us very friendly, fun, everyday, normal'.

Thus, based upon the information above, Principle 4 is supported within Peoplecare.

Stage 3 - Implementation - Principles 5 \& 6.

Principle 5 - Integrate all elements of marketing mix in rebranding implementation.

New aspects of the rebranding were integrated into the marketing mix where appropriate. For example, products were repackaged with the new logo, physical evidence including new uniforms and new marketing collateral were produced and distributed in a timely manner to relevant employees. Newly painted company vehicles emblazoned with the new logo were purchased. Principle 5 was thus supported. 
Principle 6 - Promotion needed to inform all stakeholders of revised brand.

Once the nature of the rebrand was finalised, it was subsequently announced to employees and new uniforms provided. Quirky company vehicles emblazoned in the new logo livery were introduced. Members were notified via newsletters (newly formatted) and television advertisements targeted other stakeholders. Advertisements also featured on the entire side of buses. Thus, Principle 6 was supported.

Table I provides a summary of the usage of the principles of corporate rebranding identified within Peoplecare.

INSERT TABLE I HERE

Results of the rebranding

The rebranding was implemented smoothly with no problems encountered. The Peoplecare CEO considered that employing an external consultant was expensive, but effective and a good investment - 'it didn't take long for results to come'. This finding supports Kaikati and Kaikati (2003) that senior management should utilise external brand consultants. Significantly, although management and the consultants were unaware of the existence of the Merrilees and Miller (2008) principles of rebranding, evidence of all principles was identified within the rebranding exercise. 
Many factors can affect the performance of an organisation, thus measuring the result of a corporate rebranding can be difficult and should be evaluated in relation to the original initial aims of the rebrand. Rebranding "can generate a range of reactions because corporate brands communicate to multiple stakeholders, whose expectations and interpretations may differ from one another” (Lee, 2013, p. 1127). The Peoplecare rebrand can be regarded as successful. There was little backlash from members - 'only five or six member complaints'. A member survey indicated 'they like the friendliness, the freshness, the simplicity, the everyday nature'. In the two years following rebranding, growth in membership doubled in annual percentage terms (despite already being above industry average), particularly within the younger demographic. Corporate brands serve as a navigational tool for various stakeholders including potential employees (Bonaiuto et al. 2013). Peoplecare consider the rebranding encouraged potential employees, reflected by increases in job applications. As indicated by a frontline service employee - 'an employer of choice ... particularly when we advertise for member services officers, we get a really good response from [staff at] other health funds'.

A strong corporate brand also has solid impact in creating positive customer perceptions of existing products as well as new product extensions (Hatch and Schultz, 2003). Since the rebrand, Peoplecare have leveraged the increased brand awareness and introduced various product extensions, namely dental and optometrist services, enabling further growth.

\section{Discussion}

Corporate rebranding is “an emerging area of research” (Miller et al., 2014, p. 265) hence many gaps exist. The current study adds to the corporate rebranding literature and provides some 
valuable theoretical and managerial contributions to fill gaps as well as refine and expand our current knowledge.

\section{Theoretical contributions of the study}

The first contribution is to extend examination of corporate rebranding to a new setting: the nonprofit SME arena. This current research is therefore important given the significant role such organisations play within the economy. This contribution addresses calls from Fetscherin and Usunier (2012, p. 746) that because "almost only large multinational corporations are used for illustrations or research in corporate branding” there is "definitely a need for corporate branding research to extend beyond the limited scope”. This is additionally relevant considering the unique inherent differences between large for-profit organisations and non-profit SMEs. We now possess better understanding regarding exactly 'how' a non-profit SME successfully conducted a corporate rebranding. This 'broad' first contribution is detailed into more depth in the following contributions.

The second contribution is to extend examination of the principles of corporate rebranding (Merrilees and Miller, 2008) - developed in the for-profit context in relation to generally large, multi-national for-profit organisations - to the new context of a non-profit SME. This is significant, as minimal examination of rebranding within either the non-profit or SME arenas has previously been conducted. Despite Peoplecare and the consultants having no knowledge of the Merrilees and Miller (2008) principles, the findings subsequently identified all six principles of corporate rebranding as present during the Peoplecare rebranding process. The rebranding was implemented smoothly with no apparent issues identified. This therefore provides support for the further generalisation of the six principles to the new setting. 
Whilst the Merrilees and Miller (2008) principles are supported as relevant and useful in this new setting, a key new insight, hence a third contribution arising from the findings are suggested refinements to the overall Merrilees and Miller (2008) principles of corporate rebranding and conceptual model. The first suggested refinement: Peoplecare utilised employee communication/research to assist development of the actual brand re-visioning (Theme 1), not just simply to attain internal support in Theme 2. This suggests that progress from Theme 1 to Theme 2 is not explicitly linear (as proposed by Merrilees and Miller (2008)), and that Theme 2 (Principle 4) actually overlaps and operates concurrently to assist development of Theme 1. Thus, employees should be involved in the rebranding process from the start (i.e. brand re-visioning), not simply included after Theme 1 is determined. Indeed, achieving buy-in is a lot easier if employees are involved, or at least have the opportunity for involvement from the start. The second suggested refinement: whilst Merrilees and Miller (2008) divide Theme 3 (Implementation) into two specific principles, realistically, Principle 6 (Promotion) is actually a sub-set of Principle 5 (Marketing Mix) and both Principle 5 and Principle 6 need to be conducted together. The third suggested refinement: to highlight the time component of the progression through the principles, it is recommended that a directional 'time' arrow be added to the graphical representation. These suggested refinements to the principles of corporate rebranding developed by Merriless and Miller (2008) are indicated in Table II. Namely, commence Principle 4 concurrently with Principles 1-3, and merge Principle 6 into Principle 5. Also, to clarify the timeline of introduction of each principle, the 'themes' have been re-described as 'stages' and a directional arrow included. Whilst these recommended refinements were identified based upon the current non-profit SME case study, it is suggested that these refinements are not due to any inherent characteristics of for-profit versus non-profit, or large versus smaller organisations. The refinements are relevant to both for-profit and non-profit organisations of any size, are more 
processual and provide better understanding and clarification regarding how the principles can be implemented in practice. These recommended modifications provide a key contribution and respond to Miller and Merrilees (2011, p. 317) who suggested “[o]ther studies are desirable, to reinforce this framework, modify it or replace it with a superior conceptualisation”.

\section{INSERT TABLE II HERE}

The fourth contribution is identification of aspects of the Merrilees and Miller (2008) principles that need key concern within the specific non-profit SME context. In regards to NPOs : these organisations have traditionally utilised relatively low levels of marketing due to limited resources. There can thus be resistance and scepticism from various non-profit stakeholders (including employees) regarding expenditure on brand building activities (Laidler-Kylander et al., 2007). For this reason, buy-in is more crucial and more difficult to achieve within the nonprofit sector than the for-profit sector, hence a need to invoke Principle 4 sooner rather than later, as suggested in the refined model. Non-profit employees have a strong affinity to their delivery of service to clients, so Principle 2 of retaining some aspects of the old discourse to act as a bridge is more crucial within the non-profit context. In regards to the SME aspect: relative to larger organisations, smaller organisations tend to possess less resources, both financial as well as internal expertise. This lack of funds may result in attempting to conduct the rebrand in-house, but this is fraught with danger due to the inherent lack of internal expertise. Peoplecare utilised an external consultant. Whilst acknowledging this as expensive, Peoplecare regarded this as efficient. Curiously and significantly, whilst the consultant had no knowledge of the Merrilees 
and Miller (2008) principles of corporate rebranding, evidence of all principles was identified in the actual rebrand conducted by the consultant. This finding gives some confidence that managers could conduct their own rebranding by using the principles as a guide, although there is likely to be no substitute to utilising a rebranding expert. The smaller size of SMEs relative to large organisations tends to make communication easier, with senior management often in regular direct contact with employees. Within Peoplecare, all employees were located within a single building, albeit on multiple floors, and management regularly communicated face-to-face simply by walking around the building. This is further evidence that communications in an attempt to gain buy-in and involvement of employees is easier within SMEs than larger organisations (Theme 2 - Principle 4, as well as Theme 3 - Principle 6).

The fifth contribution - a methodological contribution - is that the study demonstrates the usefulness and benefits, of using a change management perspective utilising a discourse transformation framework, to examine how the corporate rebranding was introduced. Whilst Juntunen (2014) claims to have conducted the first examination of corporate rebranding from an organisational change viewpoint, the research basically examined renaming (in three microcompanies) - not the overall process of rebranding, indeed not the principles of corporate rebranding. The current research is hence the first known research to examine the overall corporate rebranding process from a change management perspective, and the first research to use a discourse transformation framework. Utilising a discourse transformation framework enabled broader examination of the rebranding process than if the research had simply looked for evidence or otherwise of the principles of rebranding. Issues such as the suggested refinement to the principles of rebranding were discovered due to this broader examination. A key benefit of using the discourse transformation framework is an inherent focus upon not just managers, but also upon employees, who are key stakeholders in delivering the rebrand. A problem with most 
previous rebranding research is that it typically only examines management views, with literature regarding employee involvement in rebranding "limited despite its importance" (Hankinson et al., 2007, p. 237) and a worthwhile area for research (Lee, 2013). This current paper fills this gap by consciously focussing upon gaining the views of both employees and managers, not just managers. The current research importantly determines that whilst there is a difference between employee 'buy-in' and 'involvement', they are inextricably inter-twined. Involvement enables buy-in, and then ongoing (optional) involvement assists maintenance of buy-in throughout the rebranding process. This discovery was drawn from interviewing employees more so than from interviewing managers. The current research determined that opportunity for involvement should be provided to employees at the commencement of rebranding, not in Phase 2 as originally suggested by Merrilees and Miller (2008). The pioneering discourse transformation approach has thus been demonstrated to be beneficial in examining corporate rebranding.

\section{Managerial implications of the study}

The results also provide several useful and relevant managerial contributions. A criticism of previous branding/rebranding research is that it has generally been conceptual (Kärreman and Rylander, 2008), thus a major challenge for academics is to address the needs of practitioners (Lee and Greenley, 2010) and determine “what works best in practice” (Gotsi and Andriopoulos, 2007, p. 343). Understanding the issues involved in effective corporate rebranding makes an important contribution to management practice (Gotsi and Andriopoulos, 2007). The current research focussed directly upon examination of what was conducted in practice, and whether it was successful. Crucially, the research explored the experiences of both management and employees regarding the rebranding journey. This was aided via the discourse transformation framework. 
Prior to this research we had little practical understanding regarding how managers conducted corporate rebranding within non-profit SMEs. We now have an improved understanding. We now also know that the Merrilees and Miller (2008) principles of corporate rebranding, refined based upon the current research, can be recommended as a useful guide to managers of non-profit SMEs when conducting corporate rebranding. The suggested refinements also provide improved guidance for managers of for-profit and larger organisations.

As detailed in the fourth contribution above, an issue that non-profit SME managers need to wrestle with is whether to attempt to conduct corporate rebranding in-house, or employ a consultant. This is a perplexing issue for managers given the characteristic tightness of funds within NPOs and SMEs, reluctance from NPO employees to spend funds other than directly on clients, plus the traditional lack of in-house expertise in both NPOs and SMEs. The principles of corporate rebranding can be regarded as a 'resource' providing managers with guidance to conduct a rebranding without the need to employ external consultants. It should however be cautioned that implementing guidelines can often be difficult to actually achieve in practice without previous experience.

Whilst planning can be regarded as the easy part, implementation involving employees can be difficult. A key issue for management in conducting corporate rebranding is gaining buyin, and involvement of employees. This is often overlooked by managers, and cannot be overemphasised. Despite detailed planning by managers, without appropriate buy-in from employees, rebranding will likely not be successful.

\section{Limitations and future research suggestions}

The research has limitations that provide suggestions and opportunities for future research. The study has the limitations inherent in a single case study, however its value is based upon the 
ability to look in-depth into one organisation. The research extends examination of corporate rebranding to a new setting, and also extends the Merrilees and Miller (2008) principles of corporate rebranding to this new setting. Additional similar studies in various other contexts (e.g. organisations of varying sizes, in various industries, in various sub-sectors of the non-profit sector, and in various countries) have the potential to provide additional learnings. Further exploration of corporate rebranding using a change management perspective utilising a discourse transformation framework has potential to provide increased insight upon employee involvement in rebranding.

\section{Conclusion}

Using a change management perspective, the Peoplecare case study has revealed insights in the area of corporate rebranding, hence providing various implications for research and practice. Corporate rebranding is a complex process requiring managerial appreciation of various challenges and potential pitfalls (Gotsi et al., 2008). The findings of this research: that the Merrilees and Miller (2008) principles of corporate rebranding are relevant to the non-profit SME sector, plus recommended refinements to the principles and identification of specific principles requiring additional managerial attention within the non-profit SME context, provide valuable practical guidance for managers regarding 'how' to conduct a successful future corporate rebranding. The paper introduced the use of a change management perspective via a discourse transformation framework into examination of corporate rebranding and was found to generate valuable employee insights perhaps not available when examining rebranding from more traditional perspectives. 


\section{Acknowledgements}

Access to Peoplecare management and employees during this research is gratefully acknowledged, as is the insightful feedback provided by the anonymous reviewers.

\section{References}

Amujo, O.C. and Otubanjo, O. (2012) Leveraging rebranding of 'Unattractive' nation brands to stimulate post-disaster tourism. Tourist Studies 12(1): 87-105.

Andriopoulos, C. and Dawson, P. (2009) Managing Change, Creativity \& Innovation. London: Sage.

Andreasen, A.R. and Kotler, P. (2008) Strategic Marketing for Nonprofit Organisations, 7th ed, London: Pearson Education.

Baker, M.J. and Balmer, J.M.T. (1997) Visual identity: trappings or substance? European Journal of Marketing 31(5/6): 366-382.

Balmer, J.M.T. (2001) Corporate identity, corporate branding and corporate marketing: seeing through the fog. European Journal of Marketing 35(3/4): 248-291.

Balmer, J.M.T. and Gray, E.R. (2003) Corporate brands: what are they? What of them? European Journal of Marketing 37(7): 972-997.

Balmer, J.M.T., Greyser, S.A. and Urde, M. (2006) The Crown as a corporate brand: Insights from monarchies. Journal of Brand Management 14(1): 137-161. 
Baumgarth, C. (2010) Living the brand: Brand orientation in the business-to-business sector. European Journal of Marketing 44(5): 653-671.

Bonaiuto, M., De Dominicis, Illia, L., Rodríguez-Cánovas, B. and Lizzani, G. (2013) Managing employee brand attributes to attract potential future leaders. Journal of Brand Management 20(9): 779-792.

Brexendorf, T.O., Kernstock, J. and Powell, S.M. (2012) Editorial: statement from the Editors. Journal of Brand Management 19(4): 255-256.

Brophy, R. (2014) Rebrand in crisis: how Liberty came to Ireland. Journal of Strategic Marketing 22(2): 93-103.

Calderwood, E. and Freathy, P. (2014) Rebranding a federation: Insights from the UK cooperative movement. Journal of Marketing Management 30(1-2): 90-116.

Carson, D. (1990) Some exploratory models for assessing small firms’ marketing performance. European Journal of Marketing 24(11): 8-51.

Centeno, E., Hart, S. and Dinnie, K. (2013) The five phases of SME brand-building. Journal of Brand Management 20(6): 445-457.

Creswell, J. (2003) Research Design; Qualitative, Quantitative, and Mixed Methods Approaches (2nd ed.). Thousand Oaks, CA: Sage.

Creswell, J. (2013) Qualitative Inquiry \& Research Design - Choosing Among Five Approaches (3rd ed.). Thousand Oaks, CA: Sage.

Daly, A. and Moloney, D. (2004) Managing corporate rebranding. Irish Marketing Review 17(1/2): 30-36.

de Chernatony, L. (1999) Brand management through narrowing the gap between brand identity and brand reputation. Journal of Marketing Management 15(1-3): 157-179. 
de Chernatony, L. and Dall'Olmo Riley, F. (1998) Defining a 'brand': beyond the literature with experts’ interpretations. Journal of Marketing Management 14(5): 417-443.

de Chernatony, L. and Segal-Horn, S. (2001) Building on services characteristics to develop successful services brands. Journal of Marketing Management 17(7/8): 645-669.

Eisenhardt, K. (1989) Building theories from case study research. The Academy of Management Review 14(4): 532-550.

Ewing, M., Fowlds, D. and Shephard, I. (1995) Renaissance: a case study in brand revitalization and strategic realignment. Journal of Product \& Brand Management 4(3): 19-26.

Fetscherin, M. and Usunier, J-C. (2012) Corporate branding: an interdisciplinary literature review. European Journal of Marketing 46(5): 733-753.

Foucault, M. (1991) The Foucault Effect - Studies in Governmentality. London: Harvester Wheatsheaf.

Gilmore, A., Carson, D. and Grant, K. (2001) SME marketing in practice. Marketing Intelligence \& Planning 19(1): 6-11.

Gotsi, M. and Andriopoulos, C. (2007) Understanding the pitfalls in the corporate rebranding process. Corporate Communications: An International Journal 12(4): 341-355.

Gotsi, M., Andriopoulos, C. and Wilson, A. (2008) Corporate re-branding: is cultural alignment the weakest link? Management Decision 46(1): 46-57.

Gotsi, M and Wilson, A. (2001) Corporate reputation: seeking a definition. Corporate Communications: An International Journal 6(1): 24-30.

Gyrd-Jones, R.I., Helm, C. and Munk, J. (2013) Exploring the impact of silos in achieving brand orientation. Journal of Marketing Management 29(9-10): 1056-1078. 
Hankinson, P., Lomax, W. and Hand, C. (2007) The time factor in re-branding organizations: its effects on staff knowledge, attitudes and behaviour in UK charities. Journal of Product \& Brand Management 16(4): 236-246.

Hatch, M.J. and Schultz, M. (2003) Bringing the corporation into corporate branding. European Journal of Marketing 37(7): 1041-1064.

Johnston, W.J., Leach, M.P. and Liu, A.H. (1999) Theory testing using case studies in businessto-business research. Industrial Marketing Management 28(3): 201-213.

Juntunen, M. (2014) Interpretative narrative process research approach to corporate renaming. Qualitative Market Research: An International Journal 17(2): 112-127.

Kaikati, J.G. and Kaikati, A.M. (2003) A rose by any other name: rebranding campaigns that work. Journal of Business Strategy 24(6): 17-23.

Kärreman, D. and Rylander, A. (2008) Managing meaning through branding - the case of a consulting firm. Organization Studies 29(1): 103-125.

Keller, K.L. and Richey, K. (2006) The importance of corporate brand personality traits to a successful 21st century business. Journal of Brand Management 14(1/2): 74-81.

Khan, H., and Ede, D. (2009) How do not-for-profit SMEs attempt to develop a strong brand in an increasingly saturated market? Journal of Small Business and Enterprise Development 16(2): 335-354.

Knox, S. and Bickerton, D. (2003) The six conventions of corporate branding. European Journal of Marketing 37(7): 998-1016.

Laidler-Kylander, N., Quelch, J.A. and Simonin, B.L. (2007) Building and valuing global brand sin the nonprofit sector. Nonprofit Management \& Leadership 17(3): 253-277.

Lambkin, M., and Muzellec. (2008) Rebranding in the banking industry following mergers and acquisitions. International Journal of Bank Marketing 26(5): 328-352. 
Lee, N. and Greenley, G. (2010) The theory-practice divide: thoughts from the editors and senior advisory board. European Journal of Marketing 44(1/2): 5-20.

Lee, Z. (2013) Rebranding in brand-oriented organisations: exploring tensions in the nonprofit sector. Journal of Marketing Managemen, 29(9/10): 124-1142.

Lincoln, Y. and Guba, E. (1985) Naturalistic Enquiry. Beverley Hills, CA: Sage.

Melewar, T.C., Gotsi, M. and Andriopoulos, C. (2012) Shaping the research agenda for corporate branding: avenues for future research. European Journal of Marketing 46(5): 600-608.

Melewar, T.C. and Karaosmanoglu, E. (2006) Seven dimensions of corporate identity: a categorisation from the practitioners' perspectives. European Journal of Marketing 40(7/8): 846-869.

Merrilees, B. (2005) Radical brand evolution: a case-based framework. Journal of Advertising Research 45(2): 201-210.

Merrilees, B. and Miller, D. (2008) Principles of corporate rebranding. European Journal of Marketing 42(5): 537-552.

Miller, D. and Merrilees, B. (2011) Corporate Rebranding. In Burke, R.J., Martin, G. and Cooper, C.L. (eds), Corporate Reputation: Managing Threats and Opportunities. London: Gower, pp.281-303.

Miller, D. and Merrilees, B. (2013) Rebuilding community corporate brands: a total stakeholder involvement approach. Journal of Business Research 66(2): 172-179.

Miller, D., Merrilees, B. and Yakimova. R. (2014). Corporate Rebranding: an integrative review of major enablers and barriers to the rebranding process. International Journal of Management Reviews 16(4): 265-289.

Mintzberg, H. (1994) The Rise and Fall of Strategic Planning. New York, NY: Free Press. 
Motion, J. and Leitch, S. (1996) A discursive perspective from New Zealand: another world view. Public Relations Review 22(3): 297-309.

Motion, J., Leitch, S. and Brodie, R.J. (2003) Equity in co-branding: the case of adidas and the All Blacks. European Journal of Marketing 37(7/8): 1080-1094.

Muzellec, L., Doogna, M. and Lambkin, M. (2003) Corporate rebranding: an exploratory review. Irish Marketing Review 16(2): 31-40.

Muzellec, L. and Lambkin, M. (2007) Does Diageo make your Guinness taste better? Journal of Product \& Brand Management 16(5): 321-333.

Muzellec, L. and Lambkin, M. (2008) Corporate rebranding and the implications for brand architecture management: the case of Guinness (Diageo) Ireland. Journal of Strategic Marketing 16(4): 283-299.

Order for Economic Co-operation and Development (2015), Small businesses, job creation and growth: Facts, obstacles and best practices. Retrieved from http://www.oecd.org/cfe/smes/ 2090740.pdf

Park, C.W., Eisingerich, A.B., Pol, G. and Park, J.W. (2013) The role of brand logos in firm performance. Journal of Business Research 66(2): 80-187.

Patton, M. (2002) Qualitative Research \& Evaluation Methods, $3^{\text {rd }}$ ed. Thousand Oaks, CA: Sage.

Plewa, C., Lu, V., and Veale, R., (2011) The impact of rebranding on club member relationships. Asia Pacific Journal of Marketing and Logistics 23(2): 222 - 242.

Schultz, M. and Hatch, M. (2003) The cycles of corporate branding. California Management Review 46(1): 6-26.

Salamon, L. M. and Sokolowski, S. W. (2006) Employment in America's charities: A profile. http://adm-cf.com/jhu/pdfs/NED_Bulletins/National/NEW_Bulletin26_EmplyinAmericas 
Charities_2006.pdf

Singh, A.S. (2014) Conducting case study research in non-profit organisations. Qualitative Market Research: An International Journal 17(1): 77-84.

Stake, R. (1995) The Art of Case Study. London: Sage.

Stern, B.B. (2006) What does brand mean? Historical-analysis method and construct definition. Journal of the Academy of Marketing Science 34(2): 216-223.

Stuart, H. and Muzellec, L. (2004) Corporate makeovers: can a hyena be rebranded? Journal of Brand Management 11(6): 472-482.

Stuart, H. (2012). Living the corporate rebrand: the employee perspective. Corporate Reputation Review 15(3): 158-168.

Tadajewski, M. and Hewer, P. (2011) Intellectual contributions and 'gap-spotting'. Journal of Marketing Management 27(5): 449-457.

Thomson, K., de Chernatony L., Arganbright, L. and Khan, S. (1999) The buy-in benchmark: how staff understanding and commitment impact on brand business performance. Journal of Marketing Management 15(8): 819-836.

Wong, H.Y. and Merrilees, B. (2005) A brand orientation typology for SMEs: a case research approach, Journal of Product \& Brand Management 14(3): 155-162.

Wood, L.A. and Kroger, R.O. (2000) Doing Discourse Analysis: Methods For Studying Action in Talk and Text . Thousand Oaks, CA:Sage.

Yin, R.K. (1994) Case Study Research - Design and Methods, $2^{\text {nd }}$ ed. Thousand Oaks, CA: Sage. 


\section{Table I}

Principles of corporate rebranding and evidence within Peoplecare

\section{Theme 1- Brand Re-visioning}

Principle 1 - Satisfy core ideology of corporate brand, yet progress the brand to remain relevant to contemporary conditions. Supported

Peoplecare Evidence - The existing, long-established Peoplecare brand was trusted by the existing customers, many of who were long-term customers, and often second and third generation customers. Relevance maintained to existing customers with progress to target Generation Y.

Principle 2 - Retain at least some brand concepts to build a bridge from existing to revised corporate brand. Supported

Peoplecare Evidence - Personal service was maintained in service delivery, with additional electronic service aspects to target Generation Y.

Principle 3 - Meet needs of new market segments whilst also supporting existing brand segments. Supported

Peoplecare Evidence - The new Peoplecare appeals to the new, younger target segment via a modern, funky image and additional service delivery and communication methods including Facebook and Twitter social media contact, plus Apple Apps. The traditional Peoplecare personal service was retained with guarantees for humans to answer telephones rather than automated solutions.

Theme 2 - Attaining Internal Support / Stakeholder 'buy-in'

Principle 4 - High level of brand orientation via communication, training and internal marketing. Supported 
Peoplecare Evidence - Employees were involved in all aspects of rebranding process.

Theme 3 - Implementation

Principle 5 - Integrate all elements of marketing mix in rebranding implementation. Supported

Peoplecare Evidence -All aspects of marketing mix were integrated - e.g. Product (Apple

App), Promotion - new integrated program, Process (electronic delivery added), Physical evidence (new uniforms) and marketing collateral.

Principle 6 - Promotion needed to inform all stakeholders of revised brand. Supported

Peoplecare Evidence - An integrated communication strategy was utilised incorporating television advertising and vehicular signage. 


\section{Table II}

Recommended modifications to Merrilees and Miller (2008) principles of corporate rebranding.

Merrilees and Miller (2008) original principles of corporate rebranding

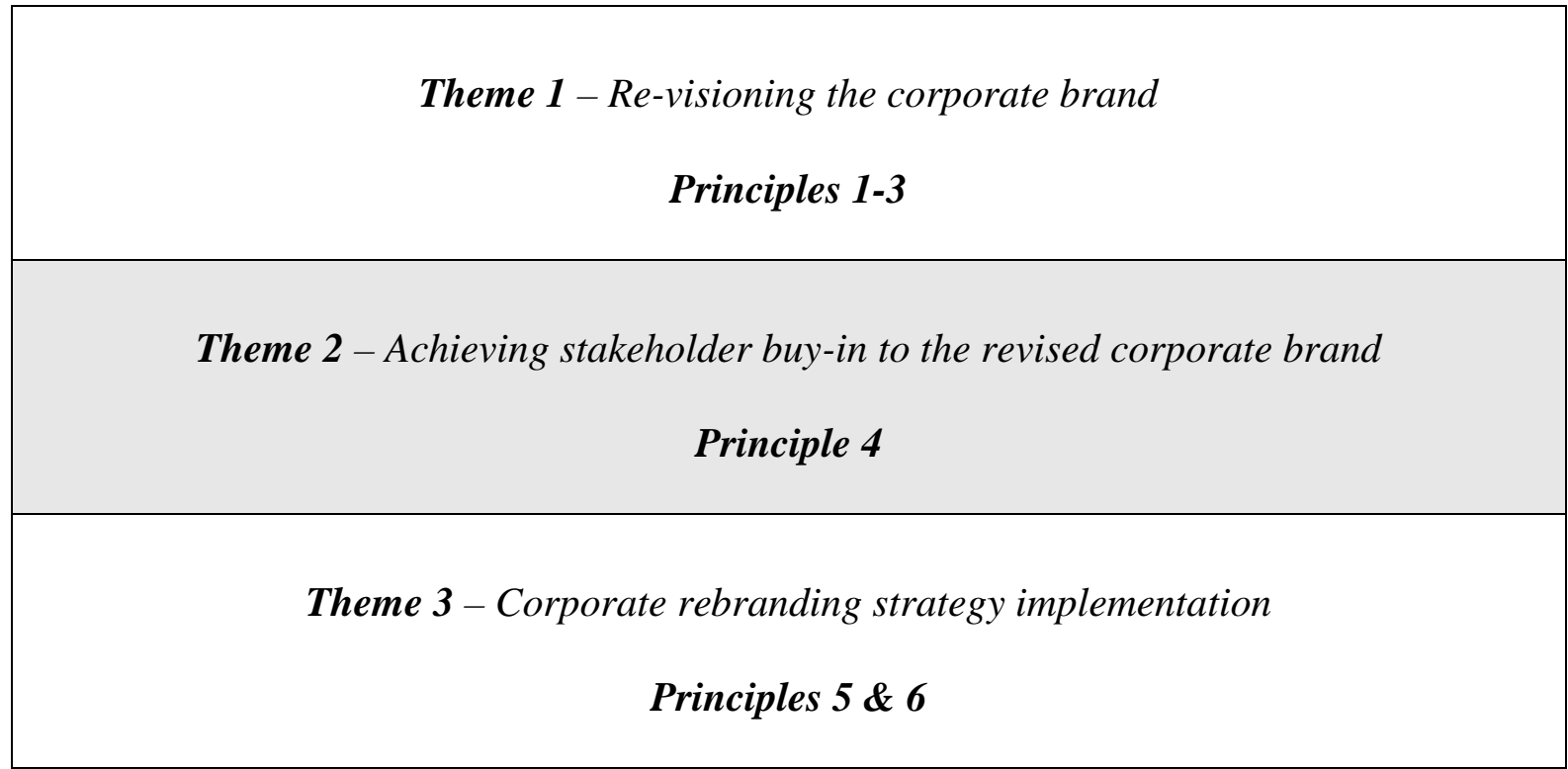

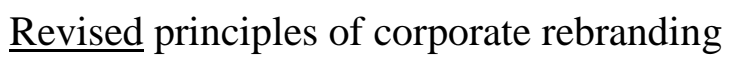

ACTIVITIES

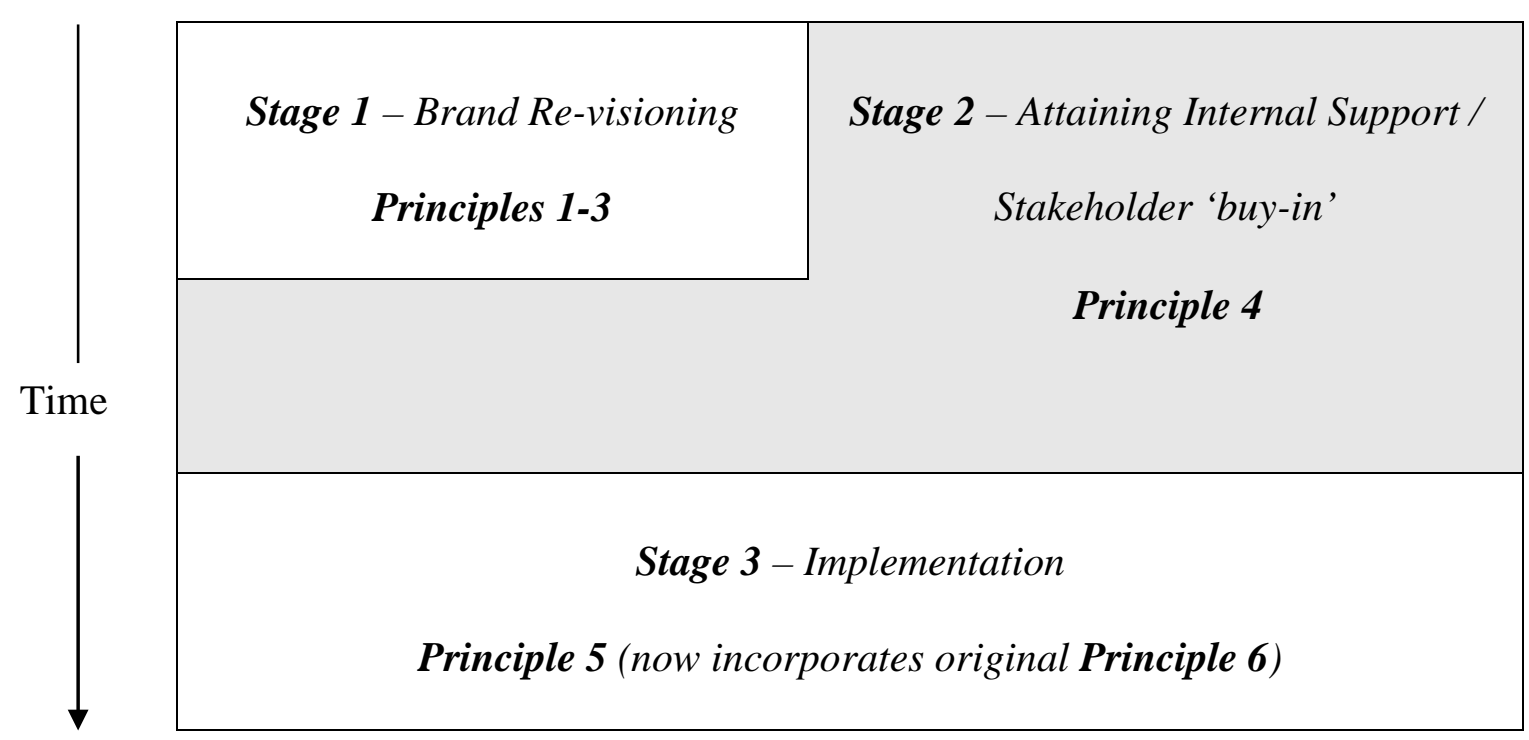


Exhibit 1 Peoplecare 'before and after' logos.
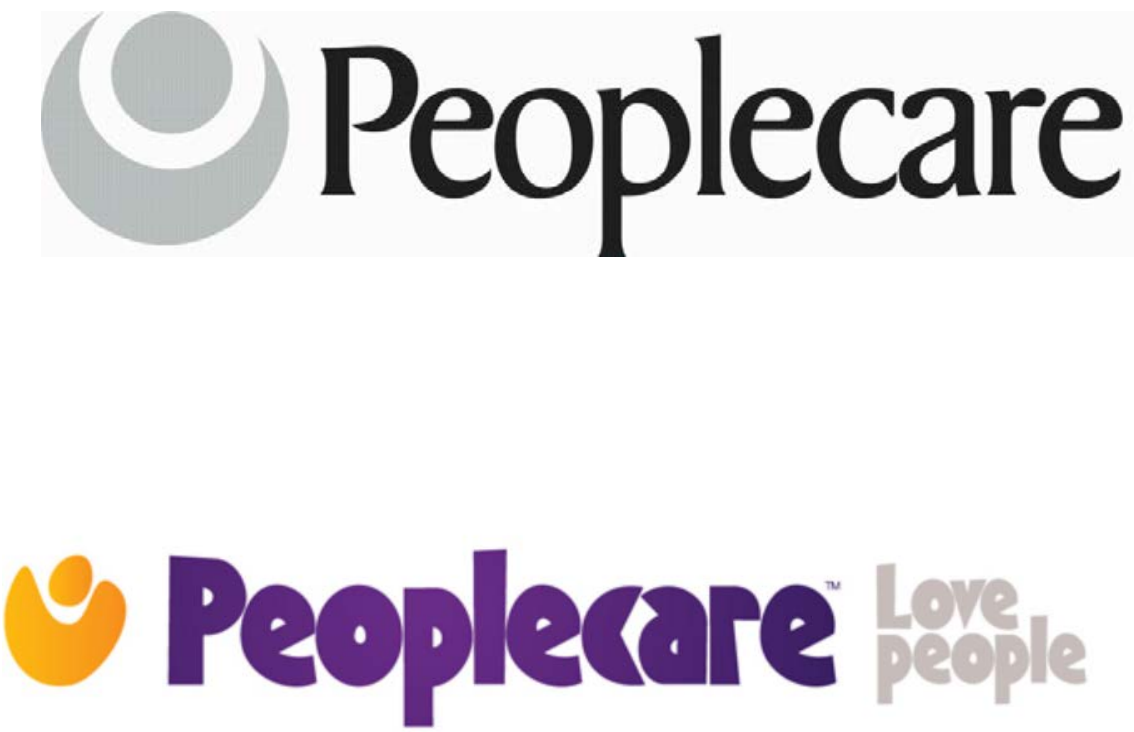

Reproduced with permission of Peoplecare. 